\title{
Constructions of the Other in Polish Fantasy Literature
}

\begin{abstract}
Even though it often follows the heroic cycle of Campbell's monomyth, because it is exomimetic, fantasy literature lends itself to the presentation of characters who are set apart from society by their nature, not just by their heroic status. These are characters such as wizards, who in fantasy are often elevated from the position of secondary characters they held in fairy tales to the stories' protagonists. This makes fantasy works a good vessel for a discussion of the problems of otherness. As the genre evolves, the presentation of the Other becomes more complex. In modern works they are often portrayed as the Other on multiple levels. As readers have become more accustomed to Tolkienian wizards, dwarves, or rangers set apart from human society, the protagonists of modern fantasy stories are often made the Other to their own in-groups. The article presents a number of such characters from selected modern Polish fantasy novels and short story cycles.
\end{abstract}

Key words: the Other, otherness, fantasy, Polish literature.

\section{Introduction}

The term Other can be used to indicate all possible differences between people, perceived as such in a given society, group, etc. (Zaniecki 1930: 173; Zamojska 2013: 192). According to Bauman (1991: 8), the notion of Otherness is crucial to the way in which societies establish categories of identity which are set up as dichotomies. Similarly, Okolie (2003: 2) stresses that social identities are relational as groups usually define themselves in relation to others: "(...)identity has little meaning without the "other". So, by defining itself a group defines others". This makes the Other necessary for creating group identity. Therefore, it is no wonder, as De Beauvoir (1974) observes, that the category of Otherness is as old as human consciousness and is a "fundamental category of human thought". As Kapuściński (2007: 36) points out, man needs another man, they seek the Other, they realize that they are unable to live without the Other.

On the other hand, the first meeting with the Other will be characterized by mistrust, uncertainty and fear. These are feelings and states that cannot be easily controlled. Although, as Kapuściński (2007: 16) argues, the Other can be perceived as an enemy and as a client, it is the circumstances that dictate whether people see a friend or a foe in one and the same person. The meeting with the Other is not simple and automatic but it involves will and effort not everyone is ready and willing to make (Kapuściński 2007: 25). 
By its very nature, fantasy and SF literature, which is exomimetic (Trębicki 2009: 9), calls for a protagonist who stands out from society and is by some virtue exceptional. It is therefore understandable that the otherness of the hero has become something of a trope in this genre. Although Tolkien's $(1994,1999)$ hobbits begin, following the pattern of Campbell's monomyth (Winkler 2012), in a state of normality, as regular and even upstanding citizens, most of his other main characters are Others: Dwarves are the Others for both humans and hobbits, as are the elves, and the Wizards, who are singular beings set apart from the world of men. Aragorn, even though he is the heir to the throne of Gondor, as one of the Dúnedain rangers, is the Other to most of human society. And Bilbo and Frodo, as they become ring-bearers, are separated from their peers and in the end have to leave Middle Earth, as they are no longer a part of it. By not allowing them to resume a normal life, the Lord of the Rings breaks the cycle of the hero's journey, which Tolkien otherwise follows quite faithfully.

This pattern, where the protagonist either is the Other by virtue of an inborn talent or fate or becomes the Other as he answers the call to adventure, repeats itself in many other works of fiction. LeGuin's (1975) Ged/Sparrowhawk, Card's (1994) Ender, and, more recently, Rowling's (2004) Harry Potter, are all separated from both society and their peers, by their inborn talents and fates, while the latter two are also shown to be the Other (at least initially) for other social reasons (Ender as the third child in a two-child society, Harry Potter as an orphan). This can in part be seen as a response to the feeling of rejection which many young people experience at some point in life. As such, they are likely to identify with the protagonist, who feels the same way, and draw consolation from it, as the character's rejection by society turns out to be intertwined with their ultimate triumph against adversity. As the fantasy and SF genres develop, authors become aware of this trope and start applying it consciously, often twisting its details or using it as a commentary on the fate the Other in our society. Thus, the genres become "a vehicle for carrying deeper meanings, often concerning matters of ultimate importance (Adamiak 2015: 189)"1.

This article discusses the construction of the Other in a number of modern Polish fantasy and SF novels and short story cycles. Three of them are fantasy stories, two are set in an alternate modern world with supernatural elements, and the last two are nominally science fiction, set on distant planets, but with strong fantasy elements. The discussed titles are:

- Tkacz Iluzji by Ewa Białołęcka (1997)

- The Wiedźmin² cycle by Andrzej Sapkowski (1990 - 2000)

- Arivald z Wybrzeża by Jacek Piekara $(1994,2008)$

- Nocarz by Magdalena Kozak (2015)

1 Pol. “(...) może się ona stać wehikułem do przemycania głębszych treści, niekiedy dotyczących spraw najważniejszych”. Authors' own translation.

2 Even if an English translation of a given work exists, we are preserving the original Polish titles for the sake of consistency. The professions of the characters will be translated where possible, but personal names will be preserved. 
- Załatwiaczka by Milena Wójtowicz (2007)

- Takeshi: Cień Śmierci by Maja Lidia Kossakowska (2014)

- Pan Lodowego Ogrodu by Jarosław Grzędowicz (2005 - 2012)

\section{Tkacz Iluzji - born Other}

The protagonist of Ewa Białołęcka's short story is a boy named Kamyk, whose otherness is an integral part not only of his main story arc, but also of his entire life. He is the son of a saddler, orphaned at an early age and born deaf, but with the gift of creating magical illusions. Thus, his otherness begins at a very early age, making him a lonely child.

After his parents' death during an epidemic he is adopted by a mage named Płowy. Despite his foster father's efforts, he does not learn to speak, although he does master sign language. Kamyk's world is a collection of soundless images (Białołęcka 1997: 8) and so are the illusions he weaves: impeccable but silent reflections of reality. This separates him even from other "weavers of Illusion", mages such as him. As his foster father says, a deaf child with a magic gift is a cruel twist of fate (Białołęcka 1997: 7).

Płowy leads a simple and modest life, but Kamyk still has more toys, books, and better clothes than other village children. He does not have to work as hard as them and enjoys more freedom (Białoęcka 1997: 194). Other boys are constantly jealous of his privileged social position and make his life unbearable, which becomes another reason for his being the Other among children. Consequently, he prefers to be left alone, to be able to read books undisturbed, and the price he pays is that he has no friends.

With age, Kamyk becomes more and more aware of the gap between him and other people. He feels deeply hurt and increasingly rebellious (Białołęcka 1997: 9). Kamyk is also convinced that having a faulty talent means that he is only a piece of a mage (Pol. kawałek maga) (Białołęcka 1997: 13). It is this belief that his talent is broken, along with the feeling of being different, that push Kamyk to leave his foster father's home to look for help and shape his further life. He wanders the country searching for someone who would be able to either cure his hearing or replace it. For that purpose he seeks out the help of a Creator mage named Pływak, who tells him that there is always a price to pay if one is born with a powerful magic gift. Until he met Pływak, Kamyk thought of his talent as good, useful, and sometimes even profitable, but little more than entertainment (Białołęcka 1997: 21). However, during his stay at Pływak's he is reminded of the story of Biały Róg, the greatest Weaver of Illusion, whose talent took away his ability to walk (Białołęcka 1997: 26). To Kamyk's surprise, Pływak tells him that he is an even more talented mage than Biały Róg was. Unfortunately, because of the connection between Kamyk's talent and his disability, Pływak is unable to help him.

Kamyk finally finds help in the form of a young dragon known to him as the Devourer of Clouds. When they meet, the dragon attempts to scare Kamyk with his roar and fails for obvious reasons, which intrigues him, leading him to establish mental communication with the boy. Thanks to the dragon's mind powers Kamyk is for the first time able to hear through his new friend's ears. In 
the end, thanks to this, Kamyk learns to add sound to his illusions. After he learns about Kamyk's powers, the dragon promises to stay with him, so that he can fix his talent. Thus, it is Kamyk's otherness that enables him to befriend the dragon.

Starting with Tolkien's Gandalf himself, a wizard's separation from society is a well-established trope in fantasy. It is also not uncommon for the protagonist to be additionally separated from his peers by exceptional power, talent, or expectation of greatness. Such is the fate of LeGuin's Sparrowhawk/Ged or Rowling's Harry Potter. What makes Kamyk distinct from these characters is his disability, which makes him an Other on a whole new level in both society at large and among magic users.

\section{Wiedżmin - the professional Other}

In creating the character of the Witcher ${ }^{3}$ in his original short story "Wiedźmin", Andrzej Sapkowski (2000) deliberately distanced himself from the common fantasy and fairy tale hero tropes, and in doing so he almost inadvertently made his protagonist the Other. In Campbell's monomyth (Winkler 2012) the hero receives the call to adventure in a situation of normality and often initially refuses the call. By making his character a professional monster hunter, motivated by money rather than heroism, Sapkowski circumvents both of these steps. What is adventure to us is a situation of normality for his protagonist, and there is no refusal of the call - his character is ready and willing to perform the task if the money is right. This reverses many of the common tropes of the selfless hero and, by denying the protagonist any sort of normality, it makes him the Other.

In later stories, by making the witchers a rare and dying profession, Sapkowski isolates the character even from the traditional Others in fantasy, such as the wizards. However, his isolation allows the protagonist to interact more easily with the Others of society, both at the top of the social ladder (wizards, nobility) and at its bottom (the downtrodden elder races: the elves, the dryads, the dwarves). In fact, in the novel series Geralt's party of adventurers is almost exclusively made up of Others, such as the female warrior-archer Milva or the elder vampire Regis (Sapkowski 1996). Even the most normal of his friends, the bard Jaskier, is a man from the fringes of society.

Thus, the witcher series becomes a natural vessel for presenting the problems of otherness, which the author makes use of in many of his stories. For example, in "Pani Jeziora" Sapkowski (1999) shows a pogrom of non-human races in Rivia. More poignantly, in stories involving the non-human guerrillas known as the Scoia'tael, who wage a war against the oppressive human society (Sapkowski 1994, 1996), the author not only showcases the plight of the Other in society, but also comments on the blurry line between a partisan and a terrorist (before terrorism became a buzz topic). In the acclaimed short story "Mniejsze Zło"4 (Sapkowski 1990), the ex-princess Renfri (who is a dark and twisted version of Sleeping Beauty) is both a (presumably) innocent victim of

\footnotetext{
3 This translation of wiedźmin is used both in the English editions Sapokowski's books and in the highly acclaimed computer game of the same title.
}

4 The title translates to "The Lesser Evil", which is a reference to the moral dilemma in the story. 
torture and persecution, and a heartless murdering monster. Torn between two evils, Geralt is in the end forced to kill Renfri and her band of brigands before they murder the whole town. The author tears down the key fantasy tropes. There is no good or evil, as everyone involved in Renfri's tragic story, including Renfri herself, is evil. All the hero can do is choose between evils, and in the end receives no prize or recognition.

Perhaps the most 'Other' character in all the witcher stories is the golden dragon Villentretenmerth, also known by the human name of Borch Trzy Kawki, who appears in one of Sapkowski's finest works, "Granica Możliwości”. As the equivalent of a witcher among dragons, who are themselves a rare and solitary species, Villentretenmerth is one of the most 'Other' beings in the world. In a deliberate reversal of common fairy tale tropes, Sapkowski makes the poor cobbler and the common village folk the actual villains of the story, thus deepening the protagonists' isolation by showing that whether they win or lose there is no place for them in this society. And yet, the conclusion of the story is hopeful: with the help of Geralt and his companions the dragon triumphs and receives his prize (a chance to further his breed), the king learns valuable, if not particularly humane, lessons, and Geralt himself gets a chance to reconnect with the love of his life.

Differently to what is seen in the monomyth and its many iterations, the witcher's world does not seem to offer a way out for the Other - there is no return from the abyss to normality. At the end of "Chrzest Ognia" (Sapkowski 1996: 333) the witcher is knighted by the Queen of Rivia and Lyria, officially receiving his so far assumed name, Geralt of Rivia, for his somewhat accidental heroics at the battle for the Jaruga bridge. Just before he receives the name the witcher introduces himself, in a moment of bitter honesty, as Geralt of nowhere (Sapkowski 1996: 332), asserting his lack of a place in society, almost as a declaration of injustice. Ostensibly, the knighting gives him this place, but the author makes it very clear that it does not provide the protagonist with a sense of belonging. On the contrary, the irony of officially receiving an assumed name he had used for years is not lost on the character. It is as if by officially receiving the name he actually loses his assumed identity, along with whatever else previously guaranteed his sense of self, and is left with nothing.

Predictably, this brief and somewhat ironic attempt at integrating with the "normal" society ends rather quickly, as Geralt abandons his new lady to pursue the personal quest for his adopted daughter Ciri. Later, during their stay in the "fairy tale" duchy of Toussaint, the whole party seem to find their place there, but as time passes they become increasingly restless and finally leave to continue with Geralt on his quest (Sapkowski 1999). Once more denying the tropes of fantasy and the cycle of the hero's journey, the author shows that the Other has to remain the Other.

\section{Arivald $z$ Wybrzerza - the Other among the Other}

Unlike Kamyk and Geralt, Jacek Piekara's Arivald z Wybrzerza is neither born nor brought up to be an outsider. Although he is a wizard when we meet him in Piekara's short stories, he has actually spent most of his career as a mercenary and a bard, only learning magic later in life. This has made him an exceptionally strong individual, but a rather inept mage. It seems that being self-taught at his age is an indication of unparalleled magical talent, but at the point of Arivald's 
entry into the world of wizardry his skills are laughable. Part of the humour of one of his early adventures - "Sekrety Tajemnego Bractwa"5 (Piekara 2008: 27-102) - is that his ineptitude and ignorance of protocol are taken by other wizards as a sign of power. These qualities make him the Other among his magic-wielding peers, who start their magical education early and at Arivald's age are significantly more skilled and knowledgeable than him. However, his lack of power is also what allows him to triumph where they could not, when he is able to avoid a number of powerful magical traps by simply refraining from using magic, which he is not sure he can perform correctly, and relying instead on his incredible physical strength and survival skills.

Unlike most wizards in fantasy, including the world described by Piekara, Arivald is also quite well integrated into the society of the small coastal principality he calls home. This is largely due to the fact that he is not a particularly powerful or imposing wizard. In fact, he actively tries to perpetuate this image, to avoid distancing himself from the princess' court. This is one of the plot points of “To, co najważniejsze” (Piekara 2008: 5-26). After successfully fending off an invasion of his homeland, Arivald finds himself separated from his companions at court by their newfound respect for him, even though his success is due to guile rather than magical prowess. In the end Arivald purposefully pretends to fumble a spell to re-establish his status as "just one of the guys".

His later adventures show Arivald as more powerful and learned, but his unusual background still gives him a distinct outlook on the world, frees him from many of the wizards' prejudices, and allows him to perform well in situations which might be challenging to his peers, such as in one of the darker stories in the series "Arivald i Wiedźmy" (Piekara 2008: 373-428), where he manages to get along with the wizards' traditional enemies, witches, or in "Ani Słowa Prawdy" (Piekara 2008: 315-372), where he is able to impress a dwarf with his physical strength and shows a deeper understanding of dwarven psychology than others would. Arivald breaks the common trope of fantasy by being the Other among his magic-wielding peers, but an accepted member of the society at large. Therefore, unlike Kamyk or Geralt, he is not a tragic figure.

\section{Nocarz - the Other of the Other of the Other}

Similarly to Arivald, Jerzy Arlecki does not start out as an Other. Although he is separated from his peers when he graduates from medical university, by not going into the medical profession but choosing to become a medical sales representative, this is hardly a radical choice. Neither is he particularly successful at selling drugs to medical professionals (Kozak 2015: 38) and he desperately needs a change from his dull and stifling life. Even though he manages to live a comfortable life, despite his mediocre successes, the feeling of being suffocated by his daily routines pushes Jerzy to accept a badly paid job offer with the Internal Security Agency (Pol. Agencja Bezpieczeństwa Wewnętrznego).

\footnotetext{
5 The original title of the story was "Arival z Wybrzeża" (Piekara 1994), but was later changed for publication in book format (Piekara 2008)
} 
Jerzy is surprised and does not really know why the Internal Security Agency wants him to join their ranks: he is not particularly fit, nor would his intelligence make him a Mensa member. This again shows him as an everyman character. He cannot think of any reason why the Agency wants him, other than that he is able to act both flexibly and consistently: features which might have been noticed by a professor he tried to sell medicine to, who put him in contact with the Agency. Little does he realise that he will be transformed into a vampire and become a member of an elite team fighting vampire renegades. Suddenly this everyman truly becomes the Other.

Contrary to his expectations, the vampires he is expected to work with are different from the ones depicted, among others, in urban legends and myths. They are the Others within the vampire community: they feed only on blood produced in laboratories, and protect humanity against other vampires. They are called Nocarze ${ }^{6}$ and are bound by Law, not by blood.

However, Jerzy or, as he is now called, Vesper, becomes the Other among the Others. His initiation, i.e. his first kill, goes well but only up to a point. He comes into direct contact with the victims of a skirmish too quickly: the sight and smell of real blood appear before he is ready to experience them. In such circumstances a Nocarz, might be tempted to hunt for real blood and consequently fall in with the renegades. To Vesper's knowledge, however, none of them has ever done such a thing. From that time on he is constantly being watched by Nidor, a captain and second in command to the team leader, who is appointed a guardian for Vesper and burdened with the task of stopping him if the worst should happen. This is a task in which he ultimately fails, as Vesper joins the renegades.

As the Other, Jerzy/Vesper is a Chinese box character: his ordinary origins and problematic transformation set him apart from his comrades, who are themselves the Other for the vampire race, which is the Other for humanity. Unlike Arivald, his otherness among his peers does not help him connect with the broader society. It is perhaps this multi-level otherness and inability to connect that allow the renegades to manipulate him, and lead to his ultimate fall from grace.

\section{Zatatwiaczka - the unwilling Other}

As a Polish student at Exeter University, Małgosia already starts out in the story as the Other. However, it is not a significant burden on her - being a foreigner does not affect her academic and social life, she has a good command of English, and even wins the university beauty pageant. The only thing she seems to find problematic is crossing the street: she never knows which way to look.

She truly becomes the Other when she inherits a house and a job from Miss Willoughby, who worked as a "fixer": a person who is able to provide people with anything they desire, as long as

\footnotetext{
6 This is a neologism coined by the author, which derives from the Polish word for Night, and so would roughly translate to English as "Nighter".

7 The Polish word used here (and as the title of the book) is "załatwiaczka", which is a neologism created by the author and is derived from the word "załatwiać", which in Polish means to "get something done" or "obtain an item or service”, usually through irregular means.
} 
they make a wish using the phrase: "Załatw mi ..." (Eng. "Get me...”). Małgosia is nice to Miss Willoughby and in return she receives a house and, unknowingly, the post of fixer attached to it. At first she gladly accepts the offer. She even feels as if she is Cinderella who has met her fairy godmother (Wójtowicz 2007: 13), although she quickly begins to have reservations.

Being a fixer comes with a number of benefits, as in order to be able to meet every possible demand of the clients, one becomes almost omnipotent. Fixers are practically immortal, since the Corporation they work for is not keen on losing its employees before their contracts terminate, and the moment a fixer is killed, they are resurrected almost instantly. Another advantage of the job is the possibility of meeting a variety of people and supernatural beings such as demons, banshees, wizards, etc. to make their clients' wishes come true. There are also no financial constraints on the fixer, and the Corporation makes its employees resistant to powers that could possess their minds (e.g. they cannot be manipulated by vampires). However, all this power and responsibility builds a barrier between the fixer and normal society. Furthermore, the moment one takes up the job one is snowed under with so many errands that social life becomes virtually impossible. This is what happens to Małgosia: her round-the-clock working hours and the fact that she can discuss her job only with people connected to the Corporation make her a recluse (Wójtowicz 2007: 35). Her roommates from the students' dormitory (where she continues to reside even after she inherits the house) start calling her: "the strange Polish girl" (Wójtowicz 2007: 317). She has no time to visit her family in Poland. She takes anti-sleep medication to be able to work non-stop. She becomes so consumed by her professional life that she does not even pay attention to her appearance anymore. She used to wear dresses and high-heeled shoes which, according to Phillip the vampire, requires a lot of self-determination in hilly Exeter (Wójtowicz 2007: 10). Now, she wears sneakers and baggy dungarees with huge pockets, where she keeps her notebook, with all the necessary business cards, phone numbers, addresses, etc. She is frequently tempted to cut her hair short or shave it off, but this would mean that her job has affected every possible aspect of her life and appearance. For that reason, Małgosia keeps her hair long and always dyed the same colour.

What distinguishes Małgosia from others in her profession is her desire not to isolate herself from the world, as most fixers do; as indeed Miss Willoughby had done, spending her life in the retreat of her living room managing her clients' requests on the phone. Even though she inherited a comfortable house, Małgosia still resides in the students' dormitory, because it gives her the illusion that there is more to her life than professional entanglements. She even tries to be romantically involved with Dominik, the boss of a commando of half-trolls employed by the Corporation to protect Małgosia from the unexpected consequences of her clients' demands and their unpredictable reactions to their dreams becoming a reality.

Małgosia also wants to find a way to terminate her contract as quickly as possible. The book ends with her determined to dig through tons of the Corporation's regulations to discover a clause that would free her from professional obligations. The source of her strength in the pursuit of freedom is her newly found love: a client who craved a new heart, which is now growing in his chest. 


\section{Takeshi - no way out of being the Other}

When readers meet Takeshi, he is unsuccessfully trying to hide the fact that he is the Other. He is a talented artist and decorator, wandering the country looking for a job. One day, he is asked to paint a portrait of Haru, the mayor's daughter. Bored with posing for the painting and irritated by Takeshi's resistance to her charms, the girl tries to guess who the painter is. At first sight he seems plain and boring, taciturn, stooping and old, but when he is surprised by a sudden noise or flash of light he moves quickly and swiftly. His hands do not resemble the hands of a peasant or even an artist. He wears many layers of clothes and hides his face under the wide brim of his hat. To her amazement Haru discovers that her portraitist is the man who singlehandedly killed 15 armed thugs in a tavern fight. She immediately falls in love with him.

The men killed by Takeshi served Mariko, a bored and violent young woman who, impressed by Takeshi's swordsmanship, furious because he slaughtered her henchmen, and in dire need of excitement, challenges Takeshi to a duel. The duel, Mariko's death, and the need to protect Haru from Mariko's brother make Takeshi discard the persona of an artist. This is one of the moments when he feels free, faithful to his true calling (Kossakowska 2014: 241). Takeshi's inability to discard his otherness parallels that of the witcher (Sapkowski 1996, 1999).

The duel shapes the course of subsequent events in the novel and lets the reader discover the Otherness of Takeshi, who is an adept of the Order of Black Water (Pol. Zakon Czarnej Wody), a magical organization dedicated to training extremely dangerous, intelligent, and ruthless warriors, spies, and killers. The years of relentless training and numerous trials took away a part of Takeshi's humanity, as he is deprived of the simplest human reactions: he cannot scream in fear or pain, he never loses consciousness, and he is immune to the effects of painkillers and drugs; even the powerful Truth Serum would not be able to break his mental barriers. Similarly to the previously discussed characters (with the possible exception of Arivald), these great benefits come with a price, the price of becoming the Other.

Nevertheless, Takeshi retains a part of his humanity, thanks to his love for an adept of another order, named Fumiko. He dares to follow a path not planned by the masters, which makes him the Other even within the order (which he will later leave).

When the masters of the order unexpectedly switched sides and betrayed some of their men during a botched revolt against the shogun, many of the adepts left the order. They were relentlessly pursued and cruelly punished. Takeshi is one of the last surviving renegades, which adds yet another level to his alienation, both by barring him from the one place he could call home and by forcing him to continually avoid capture. This requires Takeshi to hide his otherness and blend in with society, whether he wants to or not: a task at which he is, as we have seen, unsuccessful.

A discussion of this tale must include an interesting exchange between Takeshi and Fumiko, who states that "A man must (...) belong somewhere, have rules and authority figures. Be a part of 
a community. You want to decide everything on your own? By what right?"8 (Kossakowska 2014: 288). By this statement she expresses a typically Confucian, collectivist point of view, while Takeshi, who sticks to his own personal sense of honour, represents a more western, individualist attitude. This is noteworthy, as the novel's setting is inspired by medieval Japan, but the book is written by a western author. The novel's setting lets the reader assume that the sentiments expressed by Fumiko are shared by most of the presented society, adding yet another reason for Takeshi to be the Other.

One more thing which separates Takeshi from others is his future, for he seems destined to perform great deeds and even save the world. He is, however, himself unaware of this destiny. Does it make him the Other if neither he nor the people around him are aware of this? If nothing else, it is yet another reason why he cannot stop being the Other, as fate itself seems to be against it.

\section{Pan Lodowego Ogrodu - because he is the Other}

The otherness of Vuko Drakkainen, also known as Ulf Nitj'sefni (which means the Night Wanderer in the local dialect), the main protagonist of Jarosław Grzędowicz’s voluminous novel "Pan Lodowego Ogrodu" (Grzędowicz 2005-2012), is perhaps more obvious than in the other analysed books and, although Grzędowicz does not use it as a platform for discussing modern day problems, the author spells it out very clearly, especially at the beginning of the story (Grzędowicz 2005: 55-56).

The action of the novel is set on an Earth-like exoplanet, Midgaard, which makes Vuko Drakkainen an alien to the natives. He could hardly be more Other, even if he is no different in appearance from the human-like locals and speaks their language, especially since this is not a space opera and the natives are not a space-faring people accustomed to aliens. Furthermore, due to his training and biological modifications he has abilities far beyond the normal warriors of Midgaard. Although the need to remain incognito limits his use of Earth technology, at least some of his equipment is much better than what is available on Midgaard. As the story progresses Vuko loses his equipment and enhancements but develops the ability to wield what serves as magic on Midgaard (Grzędowicz 2007), replacing one form of otherness with another.

However, Vuko is not just the Other to the natives. Due to their training and biological enhancements, his whole team would stand out from most of humanity, and Vuko himself stands out from the team because he is, unlike them, a mere civilian, not a hard-as-nails special operations officer (Grzędowicz 2005: 10). In fact, his otherness is the reason why he is selected for the mission, when it turns out that only one person will be allowed to land on the planet. As his commander explains in a poignant scene at the start of the novel (Grzędowicz 2005: 55-56). He is the oldest on the team and therefore still remembers what it is like to be the only sentient species in the universe, much like the natives of Midgaard believe themselves to be. His mother is Polish, his father Finnish, and he grew up in Croatia; as his commander puts it: "Culture shock is an everyday

8 Pol. “Człowiek musi (...) Przynależeć gdzieś, mieć zasady i autorytety. Być częścią wspólnoty. Chcesz o wszystkim decydować sam? Na jakiej podstawie?” (authors’ own translation) 
occurrence for you"9 (Grzędowicz 2005: 56). Vuko is also a zealous individualist, who believes in moral law and common sense more than he does in the state and its laws. These qualities would make him unsuitable for the task if the whole team were to go, but if one person is to be sent, such qualities make Vuko the best candidate for the job. Or at least the least likely to die doing it.

Vuko, or Ulf, as he is known to the natives, does indeed manage to blend in with the locals, at least as well as can be expected under the circumstances. As his commander predicted, his unusual outlook on life, his otherness, is largely what allows him to achieve that. It seems that, regardless of his skills, enhancements and newfound powers, his attitude is essential to his survival. Vuko even expresses admiration for the simple yet honourable ways of the people of Midgaard, which are so different from Earth. He notes how his promise to Fjollsfinn, bound by his honour, is both different and more binding than a written contract on Earth (Grzędowicz 2012: chapter 4). He admires how Sylfana shakes off the shock of her brutal captivity, and how the pure simplicity of her attitude is a rare thing on Earth (Grzędowicz 2009: chapter 5). It seems that he is more suited for this more rugged civilisation than for his homeworld. Perhaps, in the end, he is more Ulf Nitj'sefni than Vuko Drakkainen. Despite being an alien interloper on Midgaard, he finds, like many outsiders in similar circumstances, both in mainstream fiction and in SF, that he is less the Other there than on his home planet.

\section{Conclusions}

The strongest common feature of all the presented characters is that they are the Other among the Others. Kamyk (Białołęcka 1997) is separated from other mages by his disability and unprecedented potential. Geralt the witcher (Sapkowski 1990-2000) is separated from his order mostly by his superb skills, but the rarity of his profession makes him stand out among other magic users. Unlike other wizards, Arivald (Piekara 1994, 2008) is a late-comer to the profession, with less magical prowess than them, but incredible physical strength, a different outlook, and an unusually friendly relation to the broader society. Vesper the Nocarz (Kozak 2015) starts out on a career path different from his colleagues, even before he becomes a vampire, and when he does he is both the Other to most vampires and to his vampire-hunting peers. Unlike most fixers, Małgosia (Wójtowicz 2007) does not embrace her new profession, and strives to preserve her link to humanity. In this, she is like Takeshi (Kossakowska 2014), who is furthermore considered a traitor by his order. Vuko Drakkainen (Grzędowicz 2005) is chosen for his mission precisely because he is the Other to his peers.

The other common motif in all of the discussed stories is the multi-dimensional nature of being the Other. All of the protagonists are the Other on a number of levels and for multiple reasons. Kamyk is a disabled mage of unparalleled power. Geralt the witcher is a mutant, a professional monster hunter, a man with no roots and no hopes for normality. As a wizard, Arivald would be the Other to most people, but due to his origins is also the Other to wizards. Vesper (Kozak 2015) is the Other to society as a vampire, the Other to vampires as a Nocarz, but also the Other to No-

9 Pol. “Szok kulturowy to dla pana codzienność” (authors’ own translation) 
carze. Małgosia the fixer (Wójtowicz 2007) is a foreigner who gains supernatural powers, which she (unlike other fixers) wants to get rid of. Takeshi (Kossakowska 2014) is an almost superhuman warrior, but a traitor to his order, an individualist in a collectivist society, and a man destined for greatness. Vuko Drakkainen (Grzędowicz 2005) is an alien who has supernatural powers and is chosen for his mission because he is the Other to his own society and team on a number of levels.

As is common in fantasy literature, in all these works being the Other is a source or side effect of the protagonists' power. Be it Kamyk's magical talent, Takeshi's fighting prowess, or a fixer's network of connections, the power is what makes the heroes the Other, but it is also being the Other which gives them power. This is a well-established trope in fantasy - it applies to classics, such as Tolkien's Gandalf, and to numerous later works. However, for many of the characters presented in this article, their otherness with respect to their own group of Others is a source of additional strength. Kamyk's unparalleled talent is inextricably linked to his disability. Arivald overcomes many obstacles by falling back on the skills he obtained before he became a wizard. Vuko is chosen for his mission specifically because his otherness from his peers makes him particularly suited for it.

Modern Polish fantasy literature tackles the issues of otherness in a variety of ways. The discussion of the problem of the Other is sometimes straightforward, but often approached more subtly, through the lens of the protagonists' separation from society and their peers. This separation usually occurs on a number of levels simultaneously, creating a more complex image of the problem. The construction of the Other in the analysed works goes beyond the most frequent image of the Other as a member of a different nation/race/culture. Finally, as in many fantasy stories, otherness is connected to the protagonists' power, but in these stories they are also the Other to their own communities.

\section{References}

Adamiak, Stanisław. 2015. Czy chrzcić Marsjan? Polska fantastyka o Bogu. Więź 1 [659].

Bauman, Zygmunt. 1991. Modernity and Ambivalence. Cambridge: Polity Press.

Białołęcka, Ewa. 1997. Tkacz Iluzji. In: Ewa Białołęcka, Tkacz Iluzji. Warszawa: SuperNOWA.

Card, Orson Scott. 1994. Ender's game. New York: Tom Doherty Associates.

De Beauvoir, Simone. 1974. The Second Sex. New York: Vintege Books A Division of Random House.

Grzędowicz, Jarosław. 2005. Pan Lodowego Ogrodu. Lublin: Fabryka Słów. Vol.1. Grzędowicz, Jarosław. 2007. Pan Lodowego Ogrodu. Lublin: Fabryka Słów. Vol.2. Grzędowicz, Jarosław. 2009. Pan Lodowego Ogrodu. Lublin: Fabryka Słów. Vol.3. Grzędowicz, Jarosław. 2012. Pan Lodowego Ogrodu. Lublin: Fabryka Słów. Vol.4. Kapuściński, Ryszard. 2007. Ten Inny. Kraków: Znak. Kossakowska, Maja Lidia. 2014. Takeshi: Cień Śmierci. Lublin: Fabryka Słów. Kozak, Magdalena. 2015. Nocarz. Lublin: Fabryka Słów. Le Guin, Ursula K. 1975. A Wizard of Earthsea. New York (etc.): Bantam Books. 
Okolie, Andrew C. 2003. Introduction to the Special Issue - Identity: Now You Don't See It; Now You Do. Identity. An International Journal of Theory and Research. Volume 3 Issue 1.

Piekara, Jacek. 1994. Arivald z Wybrzeża. Fenix 7 (34).

Piekara, Jacek. 2008. Ani słowa prawdy: opowieści o Arivaldzie z Wybrzeża. Warszawa: Agencja Wydawnicza Runa.

Rowling, J. K. 2004. Harry Potter and the Philosopher's Stone. London: Bloomsbury.

Sapkowski, Andrzej. 1990. Mniejsze Zło. Fantastyka 3/1990.

Sapkowski, Andrzej. 1994. Krew Elfów. Warszawa: SuperNOWA.

Sapkowski, Andrzej. 1996. Chrzest Ognia. Warszawa: SuperNOWA.

Sapkowski, Andrzej. 1997. Wieża Jaskółki. Warszawa: SuperNOWA.

Sapkowski, Andrzej. 1999. Pani Jeziora. Warszawa: SuperNOWA.

Sapkowski, Andrzej. 2000. Wiedźmin. In: Andrzej Sapkowski, Ostatnie życzenie. Warszawa: SuperNOWA.

Tolkien, John Ronald Reuel. 1994. Lord of the Rings. London: HarperCollins.

Tolkien, John Ronald Reuel. 1999. The Hobbit or There and Back Again. London: HarperCollins.

Trębicki, Grzegorz. 2009. Fantasy - ewolucja gatunku. Kraków: Universitas.

Winkler, Matthew. 2012. What makes a hero? TED-Ed. http://ed.ted.com/lessons/what-makesa-hero-matthew-winkler (2 May 2017).

Wójtowicz, Milena. 2007. Załatwiaczka. Lublin: Fabryka Słów.

Zamojska, Eva. 2013. Inny jako obcy. Imigranci w polskim dyskursie publicznym i edukacyjnym. Studia edukacyjne 28/13, 191-207.

Zaniecki, Florian. 1930. Studia nad antagonizmem do obcych. In: Przeglad socjologiczny t. 1. 